\title{
Analisis Variasi Ketebalan Coating Senyawa Glasir terhadap Daya Tahan Dielektrik Isolator Keramik Saluran Transmisi 150kV
}

\author{
YUSRENI WARMI, KAZNI FEBRIAN
}

Fakultas Teknik Institut Teknologi Padang, Indonesia

Email : yusreni@itp.ac.id

Received 23 Agustus 2020 | Revised 21 September 2020 | Accepted 17 Oktober 2020

\begin{abstract}
ABSTRAK
Penelitian ini bertujuan untuk mengetahui seberapa besar nilai coating isolator yang dapat ditembus listrik berdasarkan Basic Insulator Level (BIL). Metode yang digunakan dalam perhitungan tegangan tembus listrik ialah metode Anderson dalam hal ini Critical Fashover (CFO). Untuk mengetahui penurunan daya tahan dielektrik isolator dapat dilihat dari seberapa besar tegangan flashover yang dihasilkan. Hasil dari perhitungan disimulasikan dengan MATLAB logika fuzzy. Pada penelitian ini ketika isolator disetting pada coating 0,3 mm dengan waktu kejadian flash $2 \mu$ s maka tegangan flashover yang dihasilkan sebesar 1,3 MV. Hasil simulasi ini menunjukan bahwa pada coating 0,3 $\mathrm{mm}$ tegangan flashover yang dihasilkan melebihi dari BIL isolator yang sudah ditetapkan yakni sebesar 1,27 MV. Isolator dalam kondisi seperti ini dapat ditembus listrik atau daya tahan dielektriknya menurun. Secara bersamaan ketika kemampuan coating berkurang, maka dapat diklasifikasikan isolator dalam keadaan kotor.
\end{abstract}

Kata kunci: isolator, coating, dielektrik, BIL, dan fashover

\begin{abstract}
This research aims to determine the value of the insulator that can be penetrated by electricity based on the Basic Insulator Level (BIL). The method used in the calculation of breakdown voltage is the Anderson method, in this case, Critical Flashover (CFO). To know a decrease in the dielectric resistance of the insulator can be seen from whatever the voltage resulting from a large flashover. The results of the calculations simulated with fuzzy logic Matlab. In this research, when the insulator set on a coating of $0.3 \mathrm{~mm}$ with a flash event time of $2 \mu \mathrm{s}$, then flashover voltage resulted in $1.3 \mathrm{MV}$. The simulation results show that at the coating $0.3 \mathrm{~mm}$ the result of flashover voltage exceeds the BIL insulator that has been set at 1.27 MV. Insulator in this condition can be penetrated by electricity or the dielectric resistance decreases. Simultaneously when the coating ability is reduced, then can be classified as a dirty insulator.
\end{abstract}

Keyword: insulator, coating, dielectric, BIL, and flashover 


\section{PENDAHULUAN}

Faktor penting yang menentukan pembentukan polusi pada isolator ialah perubahan lingkungan yang alami dan abnormal (berpolusi). Polutan seperti garam, semen, uap dan lembab dari wilayah pantai, industri, pembangkit listrik dan hujan masing-masing ditransfer melalui kabut atau angin dan membentuk film pada permukaan isolator. Polusi dilapangan pada permukaan isolator dapat diselidiki menggunakan pengujian polusi buatan, yang menentukan kekuatan dielektrik isolator dalam kondisi tercemar (Sidthik, dkk, 2013)

Sementara itu telah ditemukan di Swedia, Jepang, Amerika Serikat, India dan negaranegara lain yang pertumbuhan ganggangnya, disertai dengan jamur dan bakteri parasit, yang mana hal tersebut merupakan fenomena luas yang terlihat pada permukaan isolator saluran transmisi di daerah tropis, subtropis, dan beriklim sedang (Ouyang, dkk, 2019). Seperti halnya dicekungan Sichuan China, analisis iklim menunjukkan bahwa suhu dicekungan tersebut sedang dan kelembabannya besar sehingga cocok untuk pertumbuhan alga di permukaan isolator, sedangkan suhu di barat laut Sichuan adalah rendah dan kelembabannya kecil, dan suhu dibarat daya Sichuan tinggi dan kelembabannya kecil, yang semuanya tidak cocok untuk pertumbuhan alga di permukaan isolator (Ouyang, dkk, 2018).

Polusi merupakan masalah umum terutama untuk isolator tegangan tinggi outdoor, yang dioperasikan di dekat kawasan industri, serta kawasan pesisir (İlhan, 2019). Polusi pada permukaan isolator dominan terjadi pada daerah industri dan dekat laut. Dimana kekuatan isolator menjadi sangat cepat turun dan dapat menyebabkan flashover dibawah tegangan yang sedang beroperasi. Biasanya flashover pada kondisi ini disebut flashover polusi (Guan, dkk, 2014). Polusi flashover dihasilkan oleh sebuah interaksi polutan isolator, kondisi basah, dan tengangan masuk (Sivaraman \& Sivadasan, 2014).

Untuk isolator yang terkontaminasi, penurunan secara drastis kekuatan isolasi listrik dapat disebabkan oleh tegangan operasi normal ketika cuaca buruk, seperti kondisi kabut atau titik embun. Dan lebih buruk lagi dapat menyebabkan flashover atau pemadaman listrik pada tegangan layanan normal (Jiang, dkk, 2013).

Ada tiga jenis utama polusi pada isolator yaitu sebagai berikut: Polusi industri, polusi industri dari isolator muncul dengan perkembangan industri, dan dikeluarkan ke atmosfer berupa, metalurgi, zat kimia, debu, asap, dan lain sebagainya. Selanjutnya polusi laut, garam yang menguap yang ada di lingkungan, akan dibawa oleh angin kepermukaan isolator Dengan berlalunya waktu lapisan ini akan cukup tebal untuk dibasahi dan menjadi konduktor. Konduktivitas lapisan ini akan tergantung pada jenis garam yang membentuknya. Kemudian polusi gurun, di beberapa zona, isolator saluran listrik sering mengalami pengendapan zat pencemar di gurun.

Pada tahun 2019, penelitian yang dilakukan oleh (Natarajan, 2019) permasalahan dalam melawan polusi pada isolator saluran transmisi adalah dengan menggunakan silikon RTV. Disamping itu terdapat permasalahan utama dari utilitas listrik tegangan tinggi yaitu flashover akibat polutan isolator, yang nantinya berdampak kepada kepuasan pelanggan. Utilitas listrik menghabiskan banyak biaya dalam pemeliharaannya dan juga masih terlalu mahal (Narayanan, dkk, 2014). Selain itu seperti halnya vandalisme pun ikut mempengaruhi keberlangsungan operasional saluran transmisi (Paularenatha, dkk, 2017). 
Di Meksiko, penggunaan isolator polimer pada saluran transmisi, dimulai pada tahun 1996. Ini dilakukan secara eksklusif di daerah dengan masalah polusi parah. Karena penggunaann isolator polimer sangat memuaskan maka isolator polimer secara sistematis menggantikan isolator kaca dan porselen pada saluran transmisi, sehingga penggunaan isolator polimer meningkat dengan signifikan (Vazquez \& Corona, 2016). Untuk isolator yang digunakan di daerah Payakumbuh-Koto Panjang adalah jenis keramik yang dilapisi senyawa glasier, sedangkan beberapa bahan yang digunakan untuk membuat glasir diantaranya silika (SiO2), feldspar, kapur (CaCO3), kaolin, Zinc Oxide, dan Rutile.

Terkait pengotoran, hal tersebut disebabkan oleh polusi disekitar wilayah isolator. Seperti halnya isolator pada penelitian ini berada didaerah perbukitan yang rentan terhadap pengotoran oleh daun-daun kering yang mati sehingga dapat menempel pada permukaan isolator, selain itu kontaminisi biologis seperti terdapatnya ganggang atau lumut yang dapat hidup atau tumbuh pada permukaan isolator juga mempengaruhi terhadap daya tahan dielektrik isolator dan peningkatan flashover. Menurut referensi (Warmi \& Michishita, 2017) berdasarkan lokasi tower sebanyak $63 \%$ berada pada daerah perbukitan, $20 \%$ daerah sawah, dan $16 \%$ daerah gurun. Dari lokasi tower tersebut sebanyak $63 \%$ daerah perbukitan terdapat $82 \%$ jumlah flashover, sedangkan $16 \%$ dan $2 \%$ masing-masing untuk jumlah flashover daerah sawah dan gurun. Hal tersebut terjadi karena saluran transmisi 150kV Payakumbuh-Koto Panjang terdapat tower 1-140 berada pada daerah dengan hari guruh pertahun/IKL sebanyak 165 hari/tahun (Warmi \& Michishita, 2018).

Oleh karena itu pembahasan yang tepat adalah analisis variasi ketebalan coating senyawa glasir terhadap daya tahan dielektrik isolator keramik saluran transmisi $150 \mathrm{kV}$ Payakumbuh-Koto Panjang yang bertujuan untuk menghitung tegangan tembus isolator yang kotor akibat debu dan polusi yang berpatokan pada standar tegangan tembus isolator (BIL). Tegangan tembus yang didapatkan berkaitan dengan coating isolator, kerena dipengaruhi oleh kotoran yang menempel pada permukaan isolator. Sehingga nantinya didapatkan pengaruh pengotoran isolator terhadap tegangan tembus dan keterkaitannya dengan variasi coating yang didapatkan.

\section{METODE PENELITIAN}

Analisis variasi ketebalan coating senyawa glasir terhadap daya tahan dielektrik isolator keramik saluran transmisi $150 \mathrm{kV}$ Payakumbuh-Koto Panjang yaitu menggunakan metode Anderson. Penggunaan metode Anderson bertujuan untuk menghitung tegangan tembus isolator yang kotor akibat debu dan polusi yang berpatokan pada standar tegangan tembus isolator (BIL). Tegangan tembus yang didapatkan berkaitan dengan coating isolator, kerena dipengaruhi oleh kotoran yang menempel pada permukaan isolator. Sehingga nantinya didapatkan pengaruh pengotoran isolator terhadap tegangan tembus dan keterkaitannya dengan variasi coating yang didapatkan, seperti yang dapat dilihat dalam Gambar 1. 


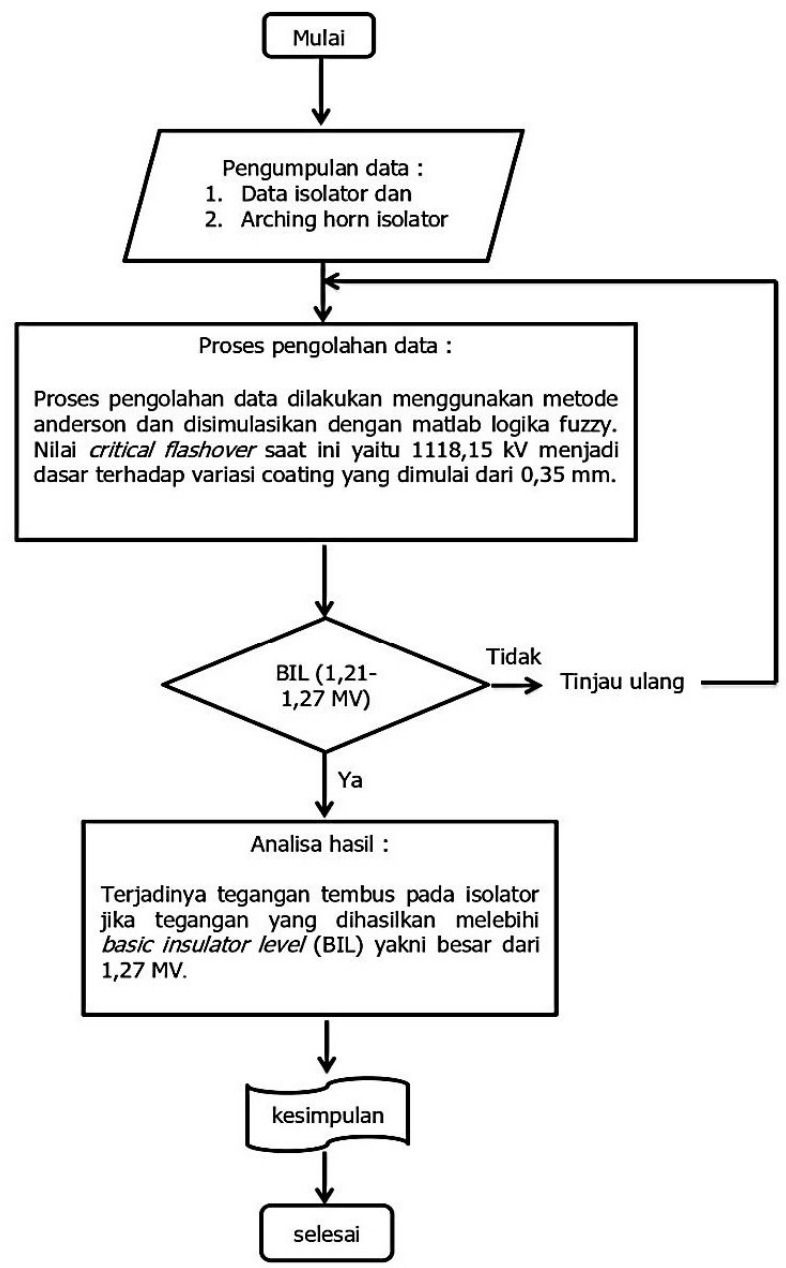

Gambar 1. Flowchart

\subsection{Metode Anderson}

Metode yang digunakan dalam menganalisa data adalah metode Anderson. Metode Anderson merupakan metode perhitungan tentang back-flashover. Back-flashover terjadi ketika sambaran petir berakhir pada kabel pentanahan sebuah menara. Sambaran memaksa arus untuk mengalir kebawah tanah. Jika volatase ini sama atau melebihi garis kritis tegangan flashover, maka akan terjadi flashover. Persamaan (1) merupakan rumus yang digunakan dalam menghitung Critical Flashover (CFO) (Warmi \& Michishita, 2018).

$$
V_{t}=\left(400+\frac{710}{t^{0,75}}\right) \times D
$$

Dimana, D merupakan jarak arching horn (m) dan t waktu tempuh gelombang petir ( $\mu \mathrm{s})$. Metode Anderson tentang backflashover memiliki 38 langkah akan tetapi pada penelitian kali ini hanya menggunakan langkah pertama saja, yaitu menghitung tegangan tembus isolator atau CFO. Tujuan penghitungan ini adalah untuk mengetahui seberapa besar nantinya isolator dapat ditebus listrik, sedangkan parameter untuk mengetahui seberapa besar isolator tembus adalah dengan berdasarkan aturan BIL yang akan tembus ketika 
tegangan isolator melebihi $1,21-1,27$ MV. Perhitungan tegangan ini digunakan untuk mengetahui seberapa besar nilai coating sebuah isolator akan tembus listrik, ketika tegangan flashover semakin besar, apakah nantinya berpengaruh besar terhadap coating, jika benar seberapa besar pengaruh coating terhadap tegangan yang dihasilkan. Oleh karena itu, metode Anderson pada langkah pertama sangat diperlukan yaitu untuk menghitung tegangan isolator sehingga nantinya dapat disesuaikan dengan aturan BIL dan pengaruh permukaan isolator yang kotor terhadap tegangan flashover dan variasi caoating yang dilakukan. Rasio perbandingan juga digunakan untuk mengetahui tegangan flashover isolator ketika isolator dalam keadaan kotor atau berpolutan.

Dalam perhitungan metode Anderson, digunakan softwere MATLAB dalam membandingkan hasil perhitungan antara logika fuzzy dengan pemograman MATLAB, selain itu juga menggunakan excel.

\section{1) Perhitungan Metode Anderson dengan Microsoft Excel}

a. Menentukan tegangan flashover isolator waktu $2 \mu \mathrm{s}$

Diketahui jarak arching horn (D) 1,36 m.

$$
\begin{aligned}
& \mathrm{t}^{0,75}=2^{\mathbf{0 , 7 5}} \\
& \mathrm{V}_{\mathrm{t}}=\left(400+\frac{710}{\mathrm{t}^{0,75}}\right) \times \mathrm{D}=\left(400+\frac{710}{2^{0,75}}\right) \times 1,36=1118,15 \mathrm{kV}
\end{aligned}
$$

b. Menentukan tegangan flashover isolator waktu $6 \mu \mathrm{s}$.

Diketahui jarak arching horn(D) 1,36 m.

$$
\begin{aligned}
& \mathbf{t}^{\mathbf{0 , 7 5}}=2^{\mathbf{0 , 7 5}} \\
& \mathrm{V}_{\mathrm{t}}=\left(400+\frac{710}{\mathrm{t}^{0,75}}\right) \times \mathrm{D}=\left(400+\frac{710}{6^{0,75}}\right) \times 1,36=795,87 \mathrm{kV}
\end{aligned}
$$

c. Rasio tegangan flashover isolator dan variasi coating isolator adalah sebagai berikut :

Rasio yang dimaksud adalah perbandingan tegangan tembus isolator dengan coating isolator, dimana keduanya adalah berbanding terbalilk. Semakin besar tegangan flashover yang dihasilkan maka ketebalan atau kemampuan coating tentunya akan semakin menurun.

(1) Tegangan flashover $\left(\mathrm{V}_{\mathrm{t}}\right)$ untuk Coating $(0,34 \mathrm{~mm})$

$$
\frac{1118,15}{\mathrm{~V}_{\mathrm{t}}}=\frac{0,34}{0,35} \longrightarrow \mathrm{V}_{\mathrm{t}}=1151 \mathrm{kV}
$$

(2) Tegangan flashover $\left(\mathrm{V}_{\mathrm{t}}\right)$ untuk Coating $(0,33 \mathrm{~mm})$

$$
\frac{1118,15}{\mathrm{~V}_{\mathrm{t}}}=\frac{0,33}{0,35} \longrightarrow \mathrm{V}_{\mathrm{t}}=1186 \mathrm{kV}
$$

(3) Tegangan flashover $\left(\mathrm{V}_{\mathrm{t}}\right)$ untuk Coating $(0,32 \mathrm{~mm})$

$$
\frac{1118,15}{\mathrm{~V}_{\mathrm{t}}}=\frac{0,32}{0,35} \longrightarrow \mathrm{V}_{\mathrm{t}}=1223 \mathrm{kV}
$$

(4) Tegangan flashover $\left(\mathrm{V}_{\mathrm{t}}\right)$ untuk Coating $(0,31 \mathrm{~mm})$

$$
\frac{1118,15}{V_{t}}=\frac{0,31}{0,35} \longrightarrow V_{t}=1262,43 \mathrm{kV}
$$




\section{2) MATLAB (Logika Fuzzy)}

Logika fuzzy dengan peningkatan logika boolean sudah mampu menentukan tingkat keabuan sebuah kasus yang berlandaskan kebenaran sebagian atau dengan konsep tidak pasti misalnya sedikit, sedang, dan sangat. Keuntungan menggunakan fuzzy adalah mudah digunakan dan pendekatan fleksibel atas masalah apa pun fuzzy juga dapat digunakan untuk masalah dengan data yang hilang atau informasi yang tidak lengkap (Agrawal \& Koley, 2016). Variabel yang digunakan pada logika fuzzy adalah 2 input dan 1 output. Input yang pertama adalah kondisi isolator dan yang kedua waktu, sedangkan outputnya adalah tegangan flashover isolator. Berikut ini merupakan rule yang digunakan :

(1) Jika isolator kotor dan waktu cepat maka tegangan flashover isolator besar

(2) Jika isolator kotor dan waktu lambat maka tegangan flashover isolator besar

(3) Jika isolator bersih dan waktu cepat maka tegangan flashover isolator kecil

(4) Jika isolator bersih dan waktu lambat maka tegangan flashover isolator kecil

Untuk menentukan kondisi isolator, apakah kotor ataupun bersih adalah ditentukan dari ketebalan coating. Ketika ketebalan coating isolator $0,3 \mathrm{~mm}$ maka kondisi isolator kotor, sampai ketika ketebalan coating isolator $0,35 \mathrm{~mm}$, maka kondisi isolator bersih. Pengklasifikasian ini didapatkan dari kondisi saat ini, yaitu ketebalan coating isolator 0,35 $\mathrm{mm}$ dengan tegangan flashover sebesar $1118,15 \mathrm{kV}$ masih dibawah tegangan BIL atau $<1,27$ MV oleh karena itu isolator tersebut diklasifikasikan dalam kondisi bersih. Sedangkan untuk coating $0,3 \mathrm{~mm}$ dengan tegangan flashover 1,3 MV, yang artinya sudah melebihi batas tegangan BIL atau $>1,27 \mathrm{MV}$, maka kondisi isolator kotor. Untuk keterangan waktu cepat dan lambat didapatkan berdasarkan metode Anderson. waktu cepat adalah $2 \mu s$ yaitu waktu awal flashover pada saluran dan waktu lambat adalah 6 Hs yaitu waktu setelah beberapa saat flashover terjadi.

Tabel 1 merupakan variabel yang akan digunakan dalam melakukan simulasi logika fuzzy, dimana terdapat dua variabel input dan satu variabel output dengan isolator sebagai input 1 dan waktu sebagai input 2 serta tegangan flashover isolator sebagai outputnya, sedangkan metode yang digunakan adalah Mamdani.

Tabel 1. Variabel yang akan digunakan dalam Simulasi

\begin{tabular}{|c|c|}
\hline Macam-macam variabel & Nama variabel \\
\hline Input 1 & Isolator \\
\hline Input 2 & Waktu \\
\hline Output & Tegangan flashover isolator \\
\hline Proses & Mamdani \\
\hline
\end{tabular}

Gambar 2 merupakan tampilan awal logika fuzzy sebelum memasuki beberapa proses berikutnya. Seperti pada Tabel 1, Gambar 2 terdiri dari dua variabel input dan satu variabel output, masing-masing yaitu isolator dan waktu, sedangkan metode atau proses yang digunakan adalah Mamdani. 


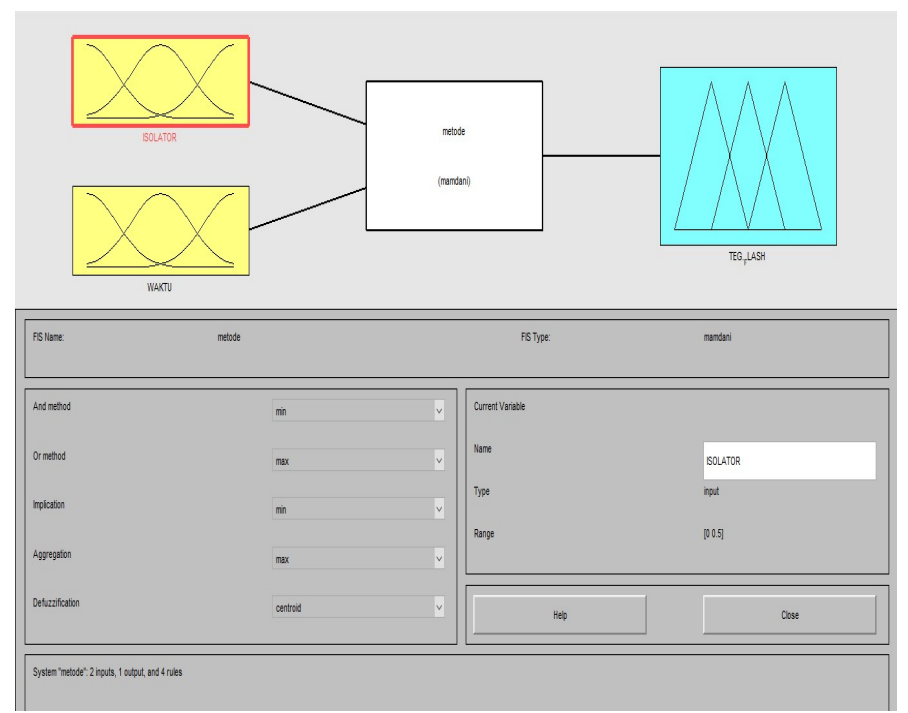

Gambar 2. Tampilan Awal Logika Fuzzy dengan 2 Variabel Input dan 1 Variabel Output

Gambar 3 merupakan isolator sebagai input satu memiliki dua himpunan, yaitu bersih dan kotor. Dimana hal tersebut memiliki korelasi dengan kondisi isolator. Untuk fungsi keanggotaan yang digunakan adalah nilai coating yaitu dari $0,3 \mathrm{~mm}$ sampai $0,35 \mathrm{~mm}$.

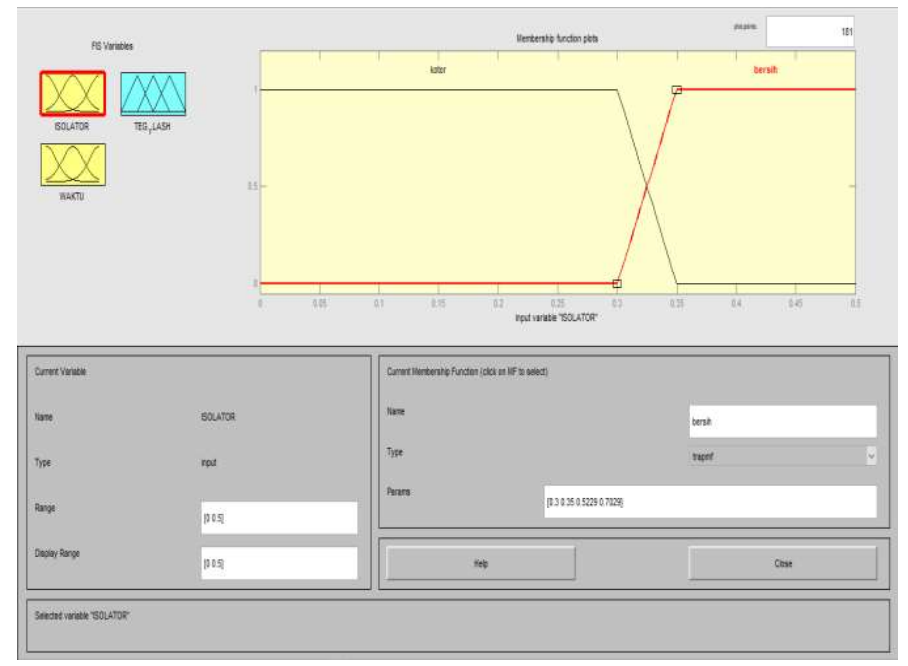

Gambar 3. Himpunan Fungsi Keanggotaan Variabel Input 1 (Isolator)

Pada input dua, himpunan yang digunakan adalah cepat dan lambat. Penggunaan himpunan ini didasari dari waktu kejadian flashover, dengan fungsi keanggotaan 2 us sampai $6 \mu$ s seperti yang ditunjukan pada Gambar 4. 


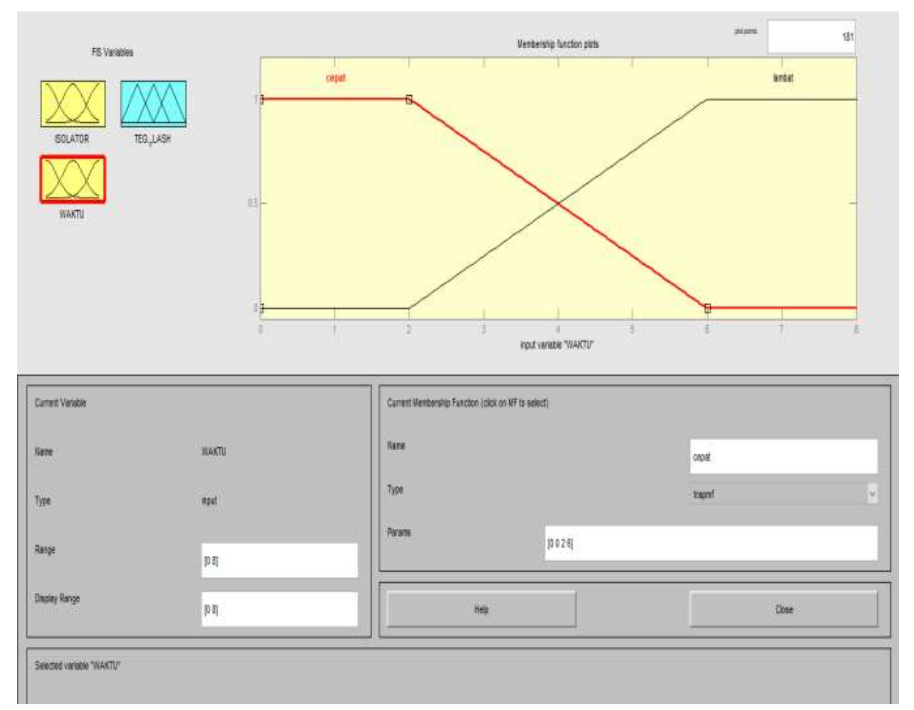

\section{Gambar 4. Fungsi Keanggotaan Variabel Input 2 (Waktu)}

Sedangkan himpunan yang digunakan pada output yaitu besar dan kecil, dengan fungsi keanggotaan 800 sampai 1300 kV seperti yang diperlihatkan pada Gambar 5. Penggunaan fungsi keanggotaan ini bertujuan untuk melihat seberapa besar nilai tegangan tembus yang didapatkan atau seberapa besar tegangan flashover isolator yang dihasilkan, sehingga nantinya dapat diklasifikasikan berdasarkan standar BIL isolator.

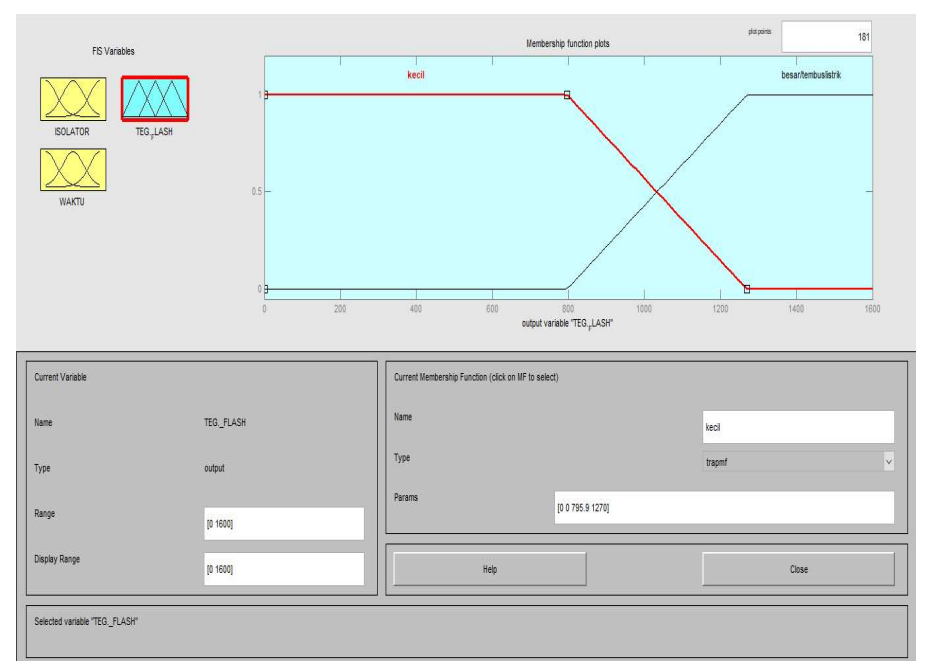

Gambar 5. Fungsi Keanggotaan Variabel Output (Tegangan Flashover Isolator)

\section{HASIL DAN PEMBAHASAN}

Pembahasan yang dilakukan adalah menentukan tegangan flashover isolator terhadap coating isolator dengan standar BIL. Menurut referensi (Warmi \& Michishita, 2016), basic insulator level (BIL) untuk satu string isolator adalah 1,21 - 1,27 MV. BIL bertujuan sebagai standar tegangan tembus isolator. 
Berikut ini merupakan hasil simulasi yang telah dilakukan :

1. Pada Gambar 6(a) dilakukan proses tuning simulasi logika fuzzy dengan input isolator 0,30 mm dan $2 \mu$ s untuk input waktunya, hasil tuning yang didapatkan seperti pada Gambar 6(b) dengan tegangan flash yang dihasilkan 1300 kV.

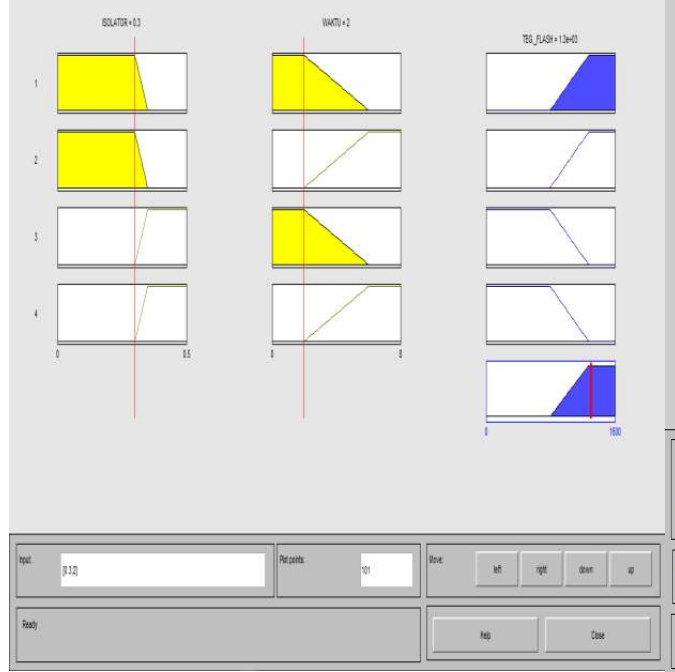

(a)

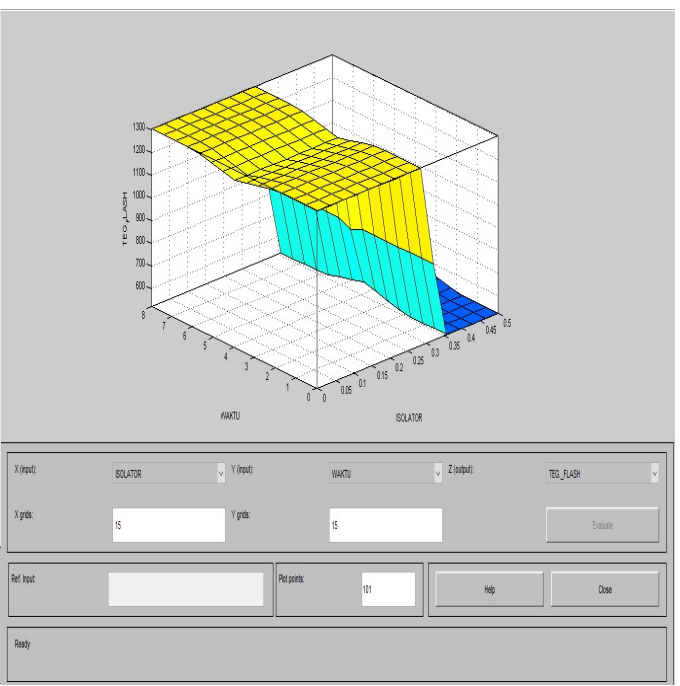

(b)

Gambar 6. (a) Proses Tuning Simulasi (Isolator/ Coating 0,3 mm dengan Waktu $2 \mu \mathrm{s}$ ) (b) Hasil Tuning Simulasi

2. Pada Gambar 7(a) dan 7(b), masing-masing merupakan proses tuning dan hasil dari simulasi. Untuk Gambar 7(a) nilai input isolator/ coating yang digunakan adalah 0,31 $\mathrm{mm}$ sedangkan untuk input waktunya adalah $2 \mu \mathrm{s}$. Sehingga hasil yang didapatkan seperti pada Gambar 7(b) dengan tegangan flash yang dihasilkan 1070kV.

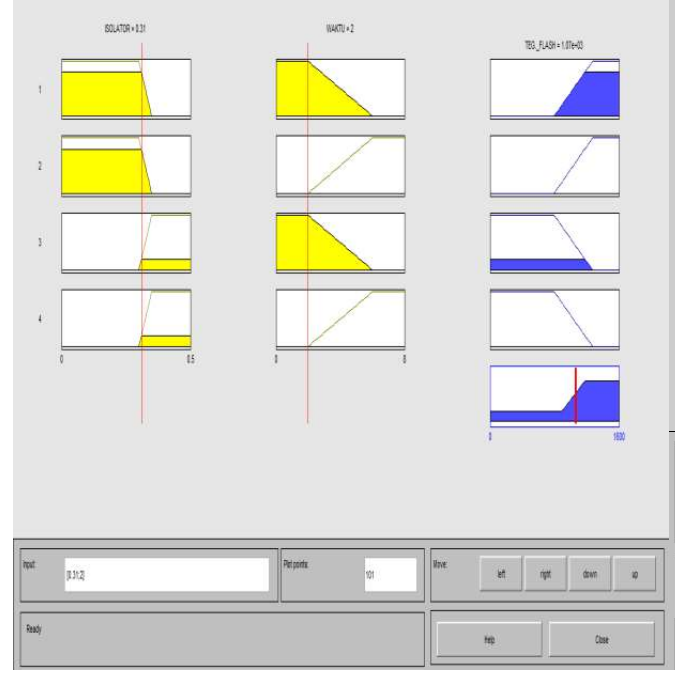

(a)

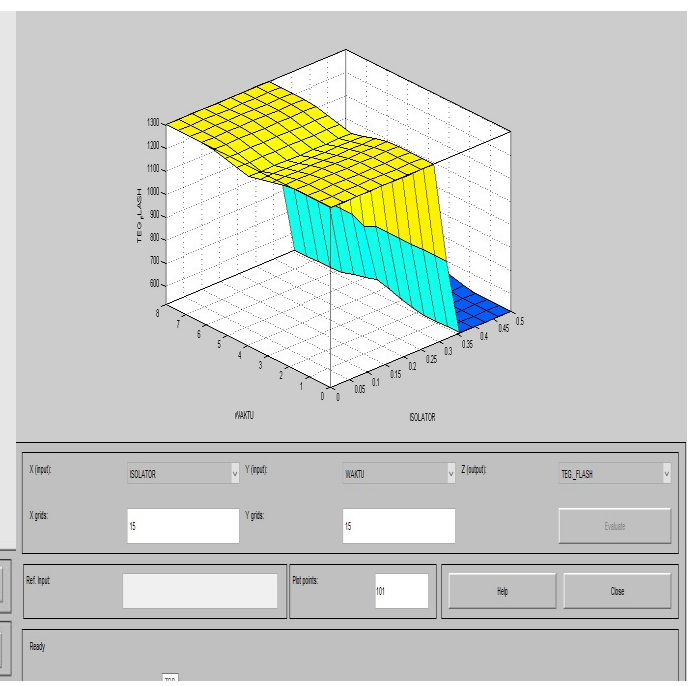

(b)

Gambar 7. (a) Proses Tuning Simulasi (Isolator/Coating 0,31 mm dengan Waktu $2 \mu \mathrm{s}$ ) (b) Hasil Tuning Simulasi 
3. Proses tuning simulasi logika fuzzy dengan input isolator/coating $0,32 \mathrm{~mm}$ dan $2 \mu \mathrm{s}$ untuk input waktunya dapat dilihat pada Gambar 8(a), hasil tuning yang didapatkan seperti pada Gambar 8(b) dengan tegangan flash yang dihasilkan 879kV.

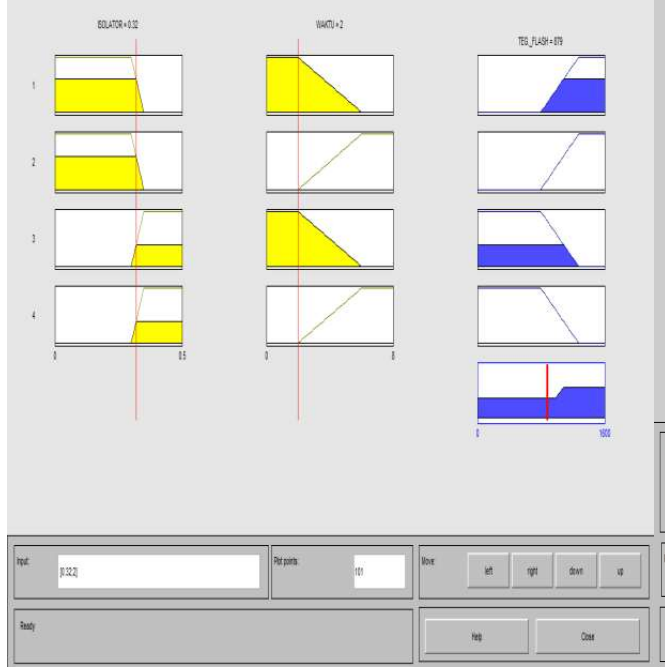

(a)

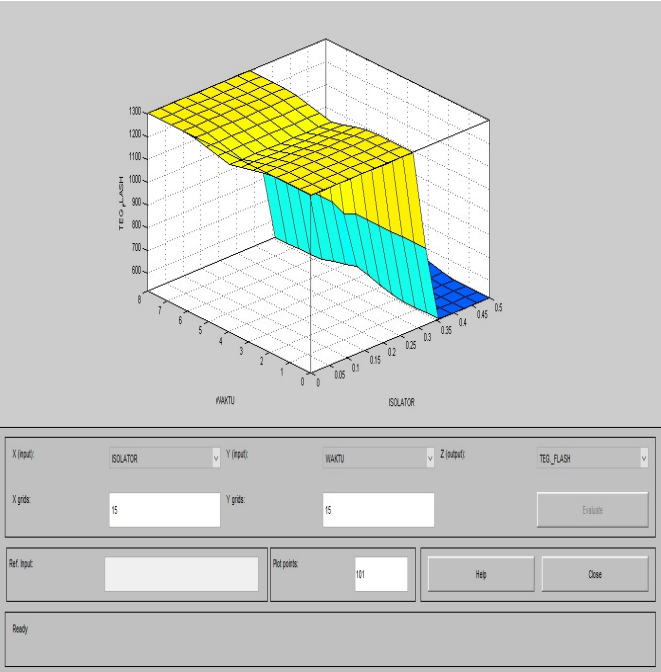

(b)

Gambar 8. (a) Proses Tuning Simulasi (Isolator/ Coating 0,32 mm dengan Waktu $2 \mu \mathrm{s}$ ) (b) Hasil Tuning Simulasi

4. Pada Gambar 9(a), input isolator/coating yang digunakan adalah 0,33 $\mathrm{mm}$ dengan input waktunya 2 ss. Hasil tuning simulasinya dapat dilihat pada Gambar 9(b) dengan tegangan flash yang dihasilkan sebesar $730 \mathrm{kV}$.

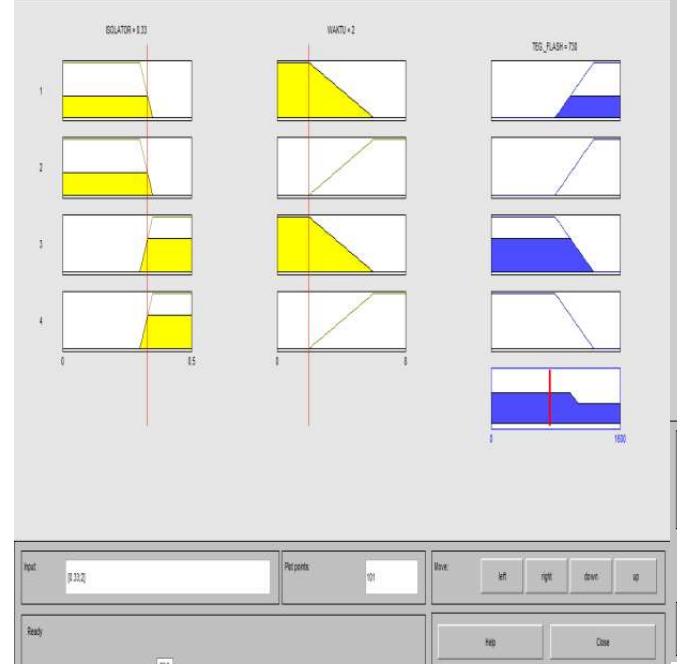

(a)

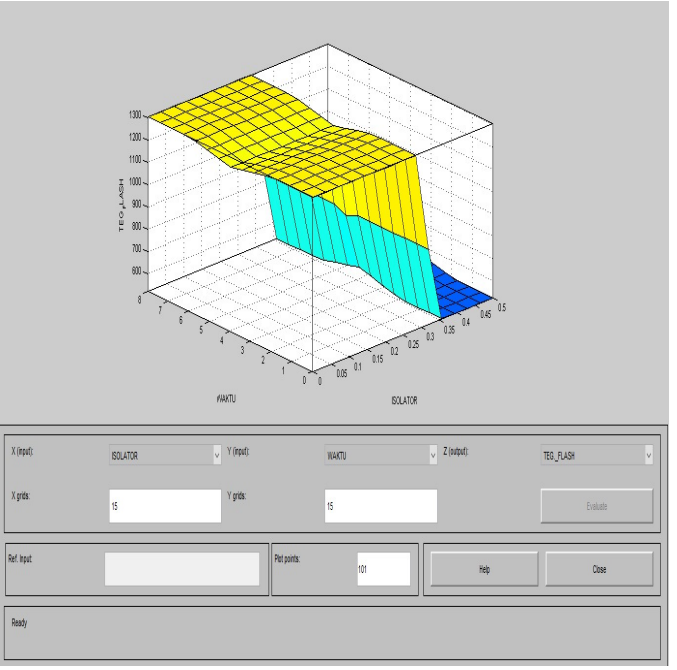

(b)

Gambar 9. (a) Proses Tuning Simulasi (Isolator/ Coating 0,33 mm dengan Waktu $2 \mu \mathrm{s}$ ) (b) Hasil Tuning Simulasi

5. Pada Gambar 10(a) dilakukan proses tuning simulasi logika fuzzy dengan input isolator/coating 0,34 mm dan 2 us untuk input waktunya, hasil tuning yang didapatkan seperti pada Gambar 10(b) dengan tegangan flash yang dihasilkan 613 $\mathrm{kV}$. 


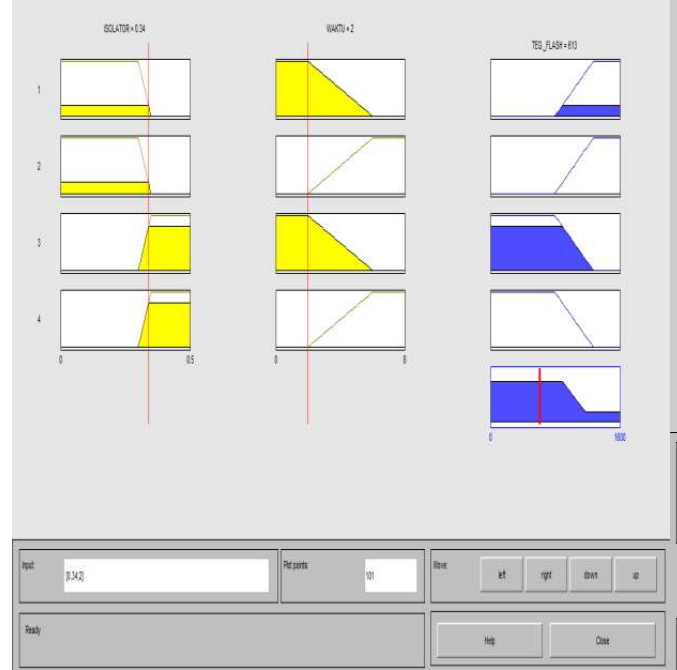

(a)

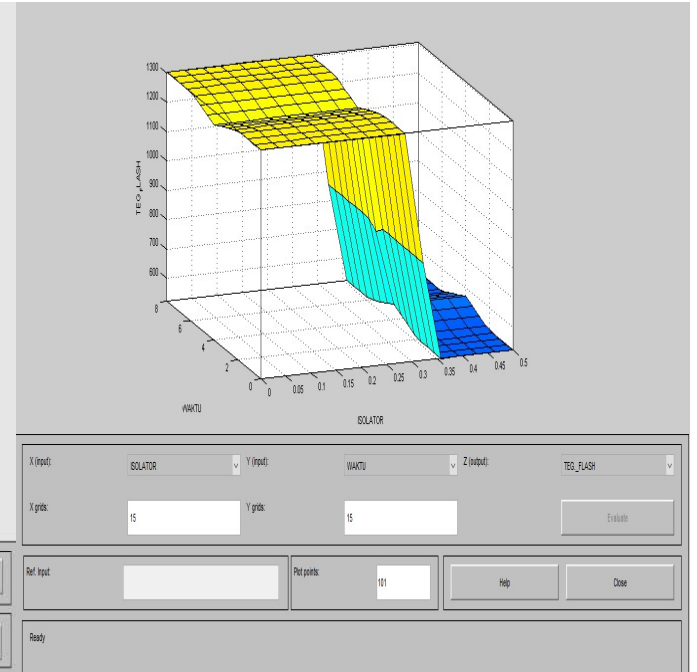

(b)

Gambar 10. (a) Proses Tuning Simulasi (Isolator/ Coating 0,34 mm dengan Waktu $2 \mu s$ ) (b) Hasil Tuning Simulasi

6. Gambar 11(a) dan 11(b) menampilkan proses tuning simulasi logika fuzzy dan hasil tuning dari simulasi dengan input isolator/coating 0,35 mm dan $2 \mu s$ untuk input waktunya, hasil tuning yang didapatkan seperti pada Gambar 11(b) dengan tegangan flash yang dihasilkan 521kV.

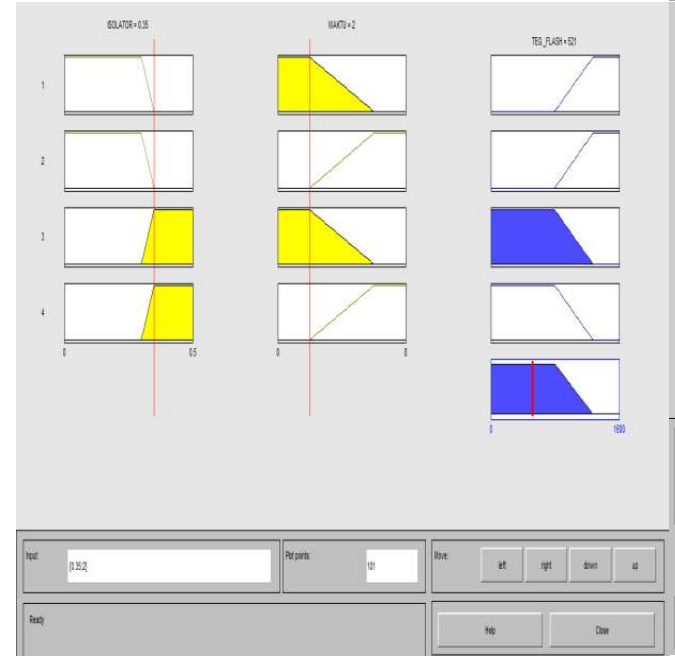

(a)

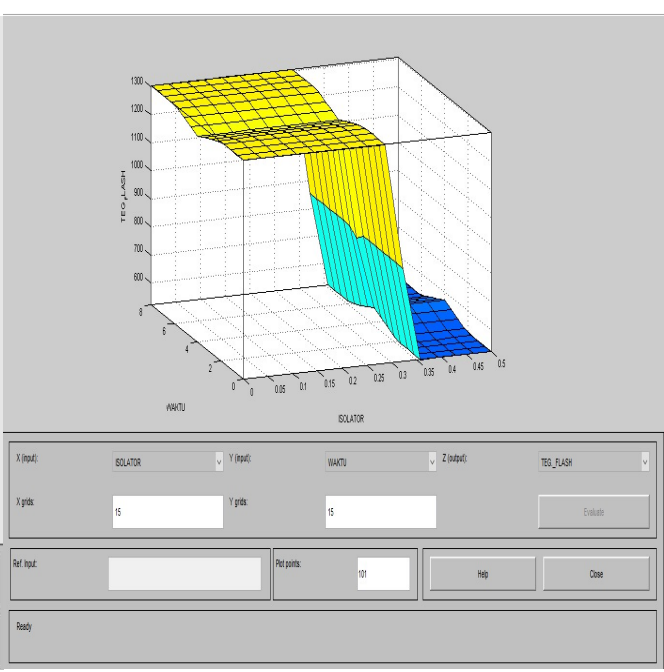

(b)

Gambar 11. (a) Proses Tuning Simulasi (Isolator/ Coating 0,35 mm dengan Waktu $2 \mu \mathrm{s}$ ) (b) Hasil Tuning Simulasi

Nilai tegangan flashover isolator $1118,15 \mathrm{kV}$ untuk coating $0,35 \mathrm{~mm}$ merupakan acuan untuk melakukan variasi coating hingga tegangan tembus melewati standar BIL (basic insulation level). Acuan ini didasari dari hasil perhitungan critical flashoveryang didapatkan dengan menggunakan metode Anderson. Begitupun untuk nilai coating yaitu dari yang terpasang saat ini pada isolator saluran transmisi 150 kV Payakumbuh-Koto Panjang. 
Tabel 2 merupakan perbandingan hasil tegangan flashover isolator antara simulasi logika fuzzy dengan perhitungan metode Anderson. Dalam Tabel 2 jelas terlihat semakin besar nilai coating maka tegangan flashover yang dihasilkan akan semakin kecil pula.

Tabel 2. Tegangan Flashover Isolator terhadap Variasi Coating dengan Waktu $2 \mu \mathrm{s}$

\begin{tabular}{|c|c|c|c|}
\hline \multirow{2}{*}{ No } & \multirow{2}{*}{ Coating $(\mathbf{m m})$} & \multicolumn{2}{|c|}{ Tegangan flashover isolator (kV) } \\
\cline { 3 - 4 } & $\begin{array}{c}\text { Perhitungan } \\
\text { metode Anderson } \\
\text { (CFO) }\end{array}$ & $\begin{array}{c}\text { Simulasi dengan } \\
\text { logika fuzzy }\end{array}$ \\
\hline 1 & 0,35 & 1118,15 & 521 \\
\hline 2 & 0,34 & 1151 & 613 \\
\hline 3 & 0,33 & 1186 & 730 \\
\hline 4 & 032 & 1223 & 879 \\
\hline 5 & 0,31 & 1262,43 & 1070 \\
\hline 6 & 0,30 & 1304,51 & 1300 \\
\hline
\end{tabular}

Gambar 12 merupakan grafik peningkatan tegangan flashover isolator terhadap variasi coating :

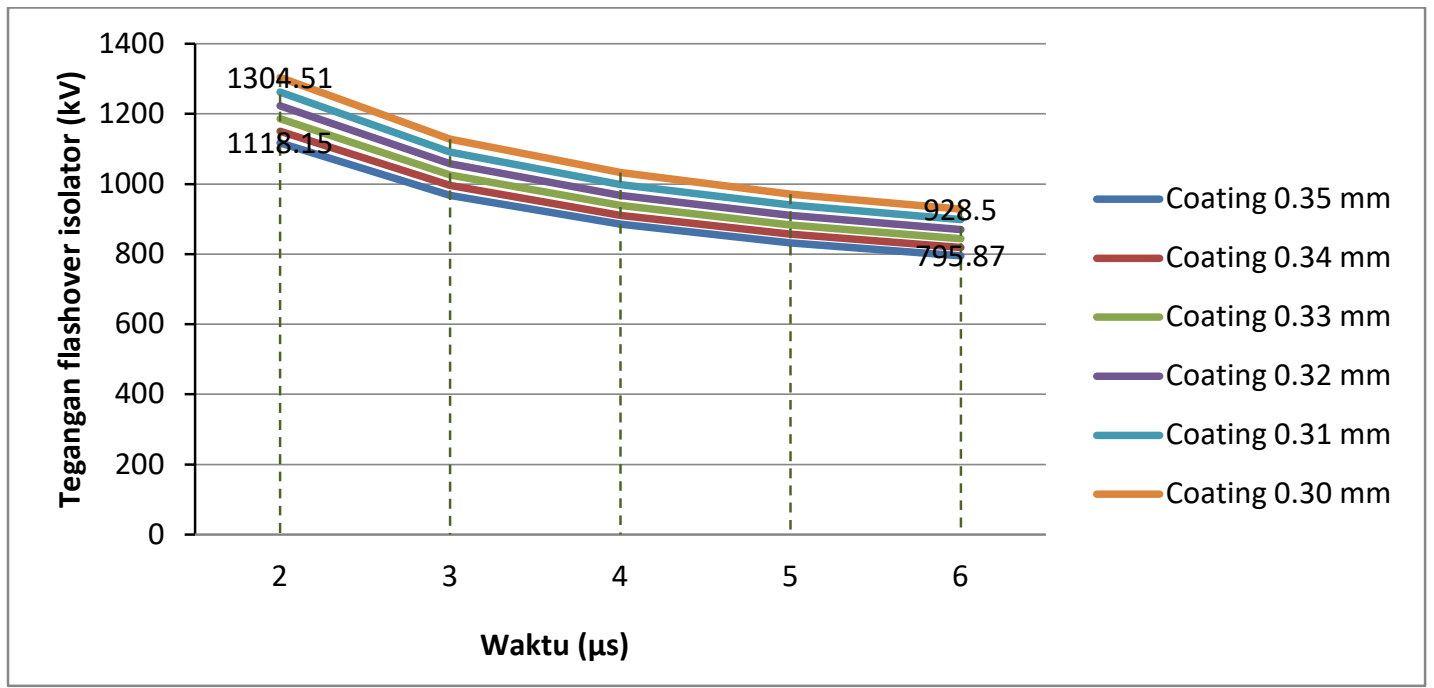

Gambar 12. Grafik Variasi Coating Isolator terhadap Tegangan Flashover

a) Variasi ketebalan coating dimulai dari $0,35 \mathrm{~mm}$ sampai $0,3 \mathrm{~mm}$. Variasi tersebut sesuai dengan besar tengangan flashover yang terjadi. Ketika tegangan flashover sudah melebihi tegangan BIL maka didapatkan ketebalan coating minimum yang nantinya berkaitan dengan kondisi isolator.

b) Coating 0,30 mm telah melewati standar BIL yaitu besar dari 1,27 MV. Ketika tegangan melewati batas maksimal maka isolatar berada pada keadaan dapat ditembus listirik, sehingga nantinya dapat menyebabkan kerusakan pada isolator atau kerusakan peralatan tegangan tinggi yang lain.

c) Penurunan ketebalan coating berbanding lurus dengan pengotoran isolator. Sedangkan coating isolator berbanding terbalik dengan tegangan flashover, semakin besar tegangan flashover isolator maka ketebalan atau kemampuan coating akan menurun. 
Analisis Variasi Ketebalan Coating Senyawa Glasir terhadap Daya Tahan Dielektrik Isolator Keramik Saluran Transmisi 150kV

Oleh karena itu jika isolator dalam keadaan kotor, besar kemungkinan untuk tembus listrik atau dibarengi dengan ketebalan coating isolator yang kian menipis.

\section{KESIMPULAN}

Dari perhitungan yang didapatkan menunjukan bahwa pada coating $0,3 \mathrm{~mm}$ tegangan flashover yang dihasilkan melebihi aturan BIL atau besar dari 1,27 MV yakni sebesar 1,30451 MV, maka pada kondisi ini dapat dikatakan bahwa isolator dapat ditembus listrik. Dan pengotoran yang terjadi pada isolator dapat menurunkan daya tahan dielektrik, dan memperbesar tegangan flashover isolator. Selain itu pengotoran yang terjadi pada isolator juga dapat mengakibatkan penurunan kemampuan coating isolator. Sehingga hasil tegangan flashover 1,3MV dengan coating $0,3 \mathrm{~mm}$ diklasifikasikan dapat mengurangi kemampuan coating dalam mencegah polutan yang menempel pada permukaan isolator, dan sangat tidak direkomendasikan untuk digunakan.

\section{DAFTAR RUJUKAN}

Agrawal, R., \& Koley, E. (2016). Fuzzy Logic based Protection Scheme for Symmetrical and Unsymmetrical Faults in Three Phase Series Compensated Transmission Line. International Conference on Micro-Electronics and Telecommunication Engineering, (pp. 471-475).

Guan, Z., Xilin, W., Xingming, B., Wang, L., \& Jia, Z. (2014). Analysis of Causes of Outdoor Insulators Damages on HV and UHV Transmission Lines in China. Electrical Insulation Conference, (pp. 227-230).

İlhan, S. (2019). Effects of RTV Coating on the Discharge Characteristics of A Suspension Glass Insulator. Electrica, 2019, 19(2), 173-181.

Jiang, X., Dong, B., Qin, H., Yin, F., Xiang, Z., \& Shu, L. (2013). Effect of Ultrasonic Fog on AC Flashover Voltage of Polluted Porcelain and Glass Insulators. IEEE Transactions on Dielectrics and Electrical Insulation, 20(2), 429-434.

Narayanan, V. J., Sivakumar, M., Karpagavani, K., \& Chandrasekar, S. (2014). Prediction of Flashover and Pollution Severity of High Voltage Transmission Line Insulators Using Wavelet Transform and Fuzzy C-Means Approach. Journal Electrical Engineering Technology, 9(5), 1677-1685.

Natarajan, A. (2019). Combating of Severe Pollution Problems on Transmission Lines without The Need for Composite Insulators. 2nd International Conference on High Voltage Engineering and Power Systems (ICHVEPS), (pp. 1-3). IEEE.

Ouyang, X., Jia, Z., Guan, R., Yang, S., \& Li, Y. (2018). Influence of Algae Growth on the Electrical Performance of RTV Coated Post Insulators. International Symposium on Discharges and Electrical Insulation in Vacuum (ISDEIV), (pp. 147-150). IEEE. 
Ouyang, X., Yin, F., Jia, Z., Yang, S., Wang, Y., Bai, H., ... Chen, H. (2019). Research of Biological Contamination and Its Effect on The Properties of RTV- Coated Insulators. Electric Power Systems Research, 167, 138-149.

Paularenatha, S., Anapaula, C., Petronio, V. J., \& Cartav, C. J. (2017). Characterization of Failures in Insulators to Maintenance in Transmission Lines. The 5th IEEE International Conference on Smart Energy Grid Engineering Characterization, (pp. 7-13).

Sidthik, A. S., Kalaivani, L., \& Iruthayarajan, M. W. (2013). Evaluation and Prediction of Contamination Level in Coastal Region Insulators Based on Leakage Current Characteristics. International Conference on Circuits, Power and Computing Technologies [ICCPCT-2013], (pp. 132-137).

Sivaraman, M., \& Sivadasan, J. (2014). Comparison of Pollution Flashover Performance of Various Insulators. International Conference on Circuit, Power and Computing Technologies [ICCPCT], (pp. 148-152).

Vazquez, I. R., \& Corona, R. H. (2016). Tracking and Erosion Requirements for High Voltage Silicone Rubber Insulators. 4-7.

Warmi, Y., \& Michishita, K. (2016). Investigation of lightning tripouts on 150-kV transmission lines in West Sumatra in Indonesia. IEEJ Transactions on Electrical and Electronic Engineering, 11(5), 671-673.

Warmi, Y., \& Michishita, K. (2017). Lightning trip-out of $150 \mathrm{kV}$ transmission line: A case study. International Review of Electrical Engineering (I.R.E.E.), 12(3), 260-266.

Warmi, Y., \& Michishita, K. (2018). Tower-footing resistance and lightning trip-outs of 150 $\mathrm{kV}$ transmission lines in west sumatra in Indonesia. MATEC Web of Conferences, 215, (pp. 4-11). 